\title{
Food solidarity economy: evaluating transition community initiatives in Friuli Venezia Giulia region
}

\author{
Lucia Piani ${ }^{*}{ }^{\mathbb{D}}$, Matteo Carzedda ${ }^{2}$ and Nadia Carestiato ${ }^{3}$
}

\author{
${ }^{*}$ Correspondence: \\ lucia.piani@uniud.it \\ 1 Department of Agricultural, \\ Food, Environmental \\ and Animal Sciences, \\ University of Udine, Via delle \\ Scienze 206, Udine, Italy \\ Full list of author information \\ is available at the end of the \\ article
}

\begin{abstract}
Climate change, ecological challenges, and economic and social crises imply paradigmatic and structural innovations. In the effort to drive transition toward sustainability, local communities often take the lead, mobilize support, and organize initiatives based on the principles of solidarity economy. Our study presents a qualitative evaluation and comparison of three local bottom-up initiatives from Friuli Venezia Giulia, a Northern Italian region, each following alternative and unique models of production and consumption of wheat and flour. The reconstruction of the transition paths of the experiences, together with documental analysis and interviews, allowed us to deduce the influence of alternative approaches and subsequent degree of effectiveness in building a community and driving it toward sustainability.
\end{abstract}

Keywords: Transition, Solidarity economy, Friuli Venezia Giulia, Food, Community

\section{Introduction}

Climate change, ecological challenges, and economic and social crises call for a new function of public policy, in order to drive transition toward sustainable development and promote local solidarity economy initiatives as possible solutions to institutional, market, and public failures (Chaves and Gallego Bono 2020). These change processes imply paradigmatic and structural innovations, involvement and participation of new actors, and redefinition of the boundaries of power, institutions, and legal frameworks. Transition is one of the key concepts used to analyze and understand such processes.

The public debate on negative environmental and social impacts of capitalism and free market has determined a shift in the global environmentalist movement toward more holistic views and perspectives. New environmentalism identifies the mainstream economic model as the leading cause of a broad range of problems, from global pollution and climate change to social inequalities, and stresses the necessity to tackle these issues at the macro (i.e., governmental and international)- as well as the micro (community)level (Connors and McDonald 2011). In this context, transition communities and the Transition Town Movement pursue local bottom-up strategies and actions to reduce their environmental impact and promote resilience and self-sufficiency (Mälgand et al.

(c) The Author(s), 2021. Open Access This article is licensed under a Creative Commons Attribution 4.0 International License, which permits use, sharing, adaptation, distribution and reproduction in any medium or format, as long as you give appropriate credit to the original author(s) and the source, provide a link to the Creative Commons licence, and indicate if changes were made. The images or other third party material in this article are included in the article's Creative Commons licence, unless indicated otherwise in a credit line to the material. If material is not included in the article's Creative Commons licence and your intended use is not permitted by statutory regulation or exceeds the permitted use, you will need to obtain permission directly from the copyright holder. To view a copy of this licence, visit http:// creativecommons.org/licenses/by/4.0/. 
2014). In the view of the Transition movement, sustainable development can only be achieved through radical changes in production and consumption patterns and requires coordination between the local and national/supranational levels (Van Der Schoor and Scholtens 2015).

The literature provides different frameworks for the analysis of transition initiatives through the evaluation of process implementation, outputs, and outcomes (Luederitz et al. 2017; Piani and Minatelli 2016). Among these, the conceptual model introduced by Forrest and Wiek (2014) provides a set of transition path reconstruction categoriesintervention action, actors, barriers, and outputs, to evaluate the impact of transition initiatives on communities and sustainability. Following this framework, the aim of the present research is to evaluate ongoing transition initiatives in Friuli Venezia Giulia (FVG) region, in Northern Italy, and define key elements for replicability and enlargement. In this region, citizens gathered in the "Forum Beni Comuni ed Economia Solidale" (Forum of the Commons and Solidarity Economy, $\mathrm{FBC})^{1}$ proposed a law to support the solidarity economy model. In 2017, the Regional Council passed the Law n. 4/2017, which establishes the legal framework for such initiatives, supports solidarity economy processes, and promotes self-sufficiency and resilience of local communities. The law recognizes local communities as the protagonists of solidarity economy and proposes the creation of new, territorially-based institutions, the Solidarity Economy Communities (SEC) (Article 4). ${ }^{2}$ Within the institutional framework of SEC, citizens have the chance to get involved by promoting the emergence of new economic spaces. The bottom-up creation of new supply chains for food, housing, clothing, and services (Article 5) redefines producer-consumer relationships, taking into account the community and the re-territorialization of the economy, and redirecting production flows from the global to the local market.

Article 3 of the law further defines solidarity economy supply chains as integrated systems whose satisfaction of basic needs shall primarily be based on: local resources; raw materials and energy saving; respect for the environment and the local landscape; protection of the rights of workers and consumers; health; active participation of citizens. Moreover, pacts and covenants should regulate and promote integration among the elements, phases and actors of the supply chains. Lastly, the law acknowledges the importance of self-production and consumption and neighborhood exchange, based on the principles of gift and volunteering, rather than economic exchange.

Our analysis sheds light on the re-territorialization of economic processes which, starting from the agri-food sector, promote the creation of new networks for local, socially, and environmentally sustainable production and distribution systems (Mance 2003). More specifically, this study focuses on three wheat-to-bread supply chain projects, localized in FVG, which originated as solidarity economy experiments within the FBC experience.

\footnotetext{
${ }^{1}$ Established in 2012, the FBC is a network of citizens and associations interested in discussing issues related to common goods and different economic practices based on the principles of environmental and social sustainability.

2 According to Law 4/2017, the spatial extent of SECs coincides with local Intermunicipal Territorial Unions ("Unioni Territoriali Intercomunali," UTI), established with Regional Law n. 26/2014. The suppression of UTIs in 2020 has sparked public debate on the identification of the new spatial dimension of SECs.
} 
Each of the three supply chain projects presents substantially different procedural approaches and alternative levels of commitment of local institutions and communities. The analysis presented in this paper highlights shared features and differences, in the light of the solidarity economy theory. Our research interfaces with other lines of research on producer-consumer relational models within the food industry (Brunori et al 2012; Renting et al. 2012); alternative food networks (Marsden et al. 2000; Renting et al. 2003; Wilson 2013); short food supply chains (Renting et al. 2003); local food systems (Hinrichs 2000; Fonte and Cucco 2017). The aim of our study is to analyze the extent to which the regional experiences studied, based on the implementation of local supply chains, can contribute to community development (L.R. 4/2017). Based on the analysis of their characteristics and development models, the experiences were analyzed according to six different aspects: main features, evolution of the process, role of community, sustainability assessment, institutional assessment, and new developments.

Section "Solidarity economy" of the manuscript introduces the theoretical basis of solidarity economy and transition as two fundamental approaches in rethinking the capitalist economic system. The methodology used in the empirical analysis is described in "Methods" section. The three projects, namely Patto della Farina del Friuli Orientale (Eastern Friuli Flour Agreement), Pan e Farine del Friûl di Mieç (Bread and Flour from Middle Friuli), and Pan e Farine di Muçane (Bread and Flour from Muzzana), are extensively described in "Case study description" section, while "Results and discussion" section presents the analysis of the experiences. Lastly, Conclusion section provides a final synthesis and identifies future prospects for research.

\section{Solidarity economy}

Scholars from different disciplines, such as anthropology, sociology, economics, have investigated the subject of economics as a science of well living. The analysis of the literature demonstrates the existence of various approaches and alternative paths toward well being within diverse economy experiences (Gomez-Alvarez 2016; Bauhardt 2014). These approaches focus either on theoretical aspects, and the criticism to the utilitarian model (Polanyi 1944; Laville 2014), or on the analysis of good practices and experiences in order to underline recurring features describing the emergence of alternative, bottom-up economic models (Gibson Graham 2014; Petropoulou 2018).

The first theoretical research stream interprets the economic behavior as a result of the interaction among a plurality of factors; in this sense, a complex set of interactions should not be reduced to the unidimensional concept of personal gain. Under this perspective, the idea of redistribution expands its application from market economy to mutually beneficial relationships, hence rejecting the separation between the State and the market, with the inclusion of social and ethical dimensions in the economy (Polanyi 1944).

The Chilean philosopher and sociologist Luis Razeto Migliaro (Razeto 1993) introduced the expression "solidarity economy" to describe alternative approaches to the economy, hence production, distribution, consumption, and saving, based on the value of solidarity. In the 1960s and 1970s, Chile and most Latin American countries experienced the emergence of authoritarian regimes which halted the post-war democratic experiments (Guerra 2009, 2014; Laville 2010). The subsequent debt crisis and social 
deregulation during the 1980s determined the exclusion from formal economy of broad sections of the population, whose livelihoods relied on informal economy initiatives and community solidarity.

The European model of solidarity economy is based on the traditions of cooperativism and social economy, as in the cases of proximity services in France and social cooperatives in Italy (Laville 1998). Consequently, solidarity economy has integrated social economy, bringing in the concepts of social utility and collective interest, and opening the discussion on the scope of social economy initiatives (Laville 2010).

The holistic view proposed by the solidarity economy approach has gradually determined its connection and integration with the concept of transition, whose origins date back to the early years of the XXI century, when Rob Hopkins founded the Transition Town Movement in Ireland (Brangwyn and Hopkins 2008; Haxeltine and Seyfang 2009). Environmentalism and critique to capitalism are the antecedents of the Transition Movement, which aims at reducing carbon emissions and building resilient communities. In the view of the founder, climate change and depletion of natural resources, primarily oil, are putting pressure on the industrial and productivist model; therefore, global perspectives as well as local actions are necessary to withstand and mitigate the consequences of upcoming crises (Connors and McDonald 2011). The Transition Movement promotes and supports grassroot efforts to address these crises (Sage 2014) and "create resilient, cooperative, and equitable communities and increase well-being at the community level" (Shawki 2013, p. 149). In this context, societal change and bottom-up initiatives drive the adoption of alternative economic and social organization models, such as decentralized community-based energy production and short food supply chains (Feola and Nunes 2014). In their attempt to strengthen communities and people's agency and resilience, transition initiatives build new relationships between communities and places, and within the communities themselves, based on cooperation, solidarity, commonality, and democratic self-determination (Felicetti 2013; Kelly and Kelly 2017).

A more empirical approach is the study of actual experiences, linked by similar practices and features, and shared values and ethics, such as solidarity-based purchasing groups (SPGs), social cooperatives, local supply chains, community gardening initiatives, time banks, ethical finance, self-help groups, non-governmental organizations (NGOs), voluntary associations (Bauhardt 2014). The panorama of experiences is variegated, as argued by scholars who, through an anthropological approach, shed light on "economic practices and everyday interactions associated with making a living, surviving, getting by, getting ahead, gaining respect, building a future, maintaining habitats, and juggling different regimes of value" (Gibson Graham 2014). As appointed by Narotzky and Besnier (2014), this results in a chaotic landscape of complexity, in which the theory has little to say to empirical experience.

Notwithstanding the differences in terms of activities and scopes, these experiences share a common grassroots relationship system, through which new rules of social life and economic interactions are put to test. Individuals who participate in similar initiatives aim at living well with and within society, at a precise moment in time, in which the State and the economy are subject to respect and satisfy the needs of nature and the human beings, rather than maximize individual utility (Williams 2014). The link with contemporary reality is another binding element, as these initiatives often respond to 
the inefficiencies of capitalism by experimenting alternatives. These initiatives generally share values and common practices, namely: the defense and promotion of human dignity; the commitment to environmental sustainability in the production of goods and services; individual-focused, rather than capital-focused, decision-making processes; social justice through fair redistribution of revenues; transparent and democratic management; self-organization; mutualism; cooperation (Hudson 2018). Laville (2014) summarizes this analysis, suggesting that the institutional base of the solidarity economy consists of the self-organization of civil society and social protection through civic rules.

In summary, solidarity economy sets the stage for local proximity development models, through the activation of networks and relationships among the actors of the civil society, business, and institutions, and the promotion of new cooperative models which take into account the ethic dimension of the economy (Moraes Soares et al. 2016).

Legal recognition of solidarity economy and related initiatives is not homogenous. In Latin America, solidarity economy is formally recognized at the constitutional level (Ecuador) or under specific framework laws (Brazil and Colombia). In Europe, the French Parliament passed a law on social solidarity economy (Loi Economie Sociale et Solidaire, LoiESS) in 2014, and similarly did Greece in 2016 (Law 4430/2016 on Social and Solidarity Economy), while in Italy this subject is devolved to the authority of regional and local governments. At present, besides FVG, the Autonomous Province of Trento (provincial law n. 13/2010) and the Emilia Romagna Region (regional law $n$. 19/2014) passed laws on solidarity economy, even though the FVG regional law is the only one that identifies local communities as the protagonists of transition toward a different socioeconomic model.

\section{Methods}

As the research streams on solidarity economy and transition communities are at an early stage of development, exploratory approaches are mandatory to contribute to define space, trends, and main themes. In the attempt to holistically analyze and represent the complexity of the social experiences selected in this research (Padgett 2017), the case study methodology was selected. The qualitative method of case studies (Yin 2003) provides the opportunity to explore and describe contextualized phenomena using a variety of data sources and emphasizing theory building rather than theory testing. The role of the researcher is to identify relevant topics or questions, determine meaningful and representative cases, and carefully analyze multiple information sources on the phenomenon.

The present research focuses on three local solidarity economy experiences to evaluate ongoing processes as transition paths toward the establishment of regional SECs (L.R 4/2017). Prospectively, SECs are intended as the founding elements of an economically, socially, and environmentally sustainable and viable system. In order to investigate these aspects, we combined existing analytical frameworks (Forrest and Wiek 2014; Luederitz et al. 2017; Silajdžić et al. 2015), to guide case study analysis toward the identification of practical guidelines for transitions experiences. The reference frameworks are based on three main elements: (1) descriptive analysis of the results; (2) assessment of 
the sustainability of the results; and (3) identification of the critical factors through the reconstruction of the transition path.

In order to draw a complete, multi-perspective representation of each of the three experiences analyzed, 10 semi-structured, face-to-face interviews were performed in 2018, together with documentary analysis, multimedia collection, and direct participation to the events. The main actors and stakeholders of the three supply chains were interviewed: projects activators and founders (local administrators for the Pan e Farine del Friûl di Mieç and Pan e Farine di Muçane projects, the miller for the Patto della Farina del Friuli Orientale); farmers, bakers, and other supply chain actors; the president of the Friul di Miec cooperative; the operation manager of the Muzzana social cooperative; representatives of the community and consumers involved in the Patto della Farina. The basic structure of the interviews was designed to gather complete and useful information to assess their evolutionary path with respect to the following aspects:

- what happened-characteristics of the path: intervention sector; objective definition; output production; product certification; order production and management; sale and distribution logistics; outputs or outcomes;

- how the process evolved-start up: selected strategies or actions; startup process description; meeting summoner; involvement models; communication and summon channels; merchandising and informative material; presence of a brand/logo;

- community assessment-role of the community: community of reference and its evolution; spatial extent of the initiative; role of local institutions; self-awareness/identity; participants' sense of responsibility and involvement; existence and development of networks within and around the experience;

- Sustainability assessment-sustainability: ability of the experiment to maintain its path; volunteer participation and duties; induced jobs; community changes in consumption models;

- institutional assessment-coherence with the legal framework (L.R 4/2017);

- new/recent development-recent and planned projects; expected evolution of the organizational model; future plans; recognitions/awards; main weaknesses; main points of strength.

Later on, the research included further follow-up activities and updates on recent developments of the three projects.

Graphical syntheses were produced to represent the development and transition path for each case study. The graphical representation contributes to clarify the chronological development of the experiences, as well as display connections among actors and strategies. In conclusion, the analysis of the information collected was summarized through the use of comparative tables/frames.

\section{Case study description}

Being their spatial extent defined by the boundaries of municipalities and the region, the three case studies presented in this research share a similar operational context, which is characterized by geographical proximity. Moreover, the three models heavily integrate production, processing, and consumption (Dunn et al. 2010; Galli et al. 2015): 


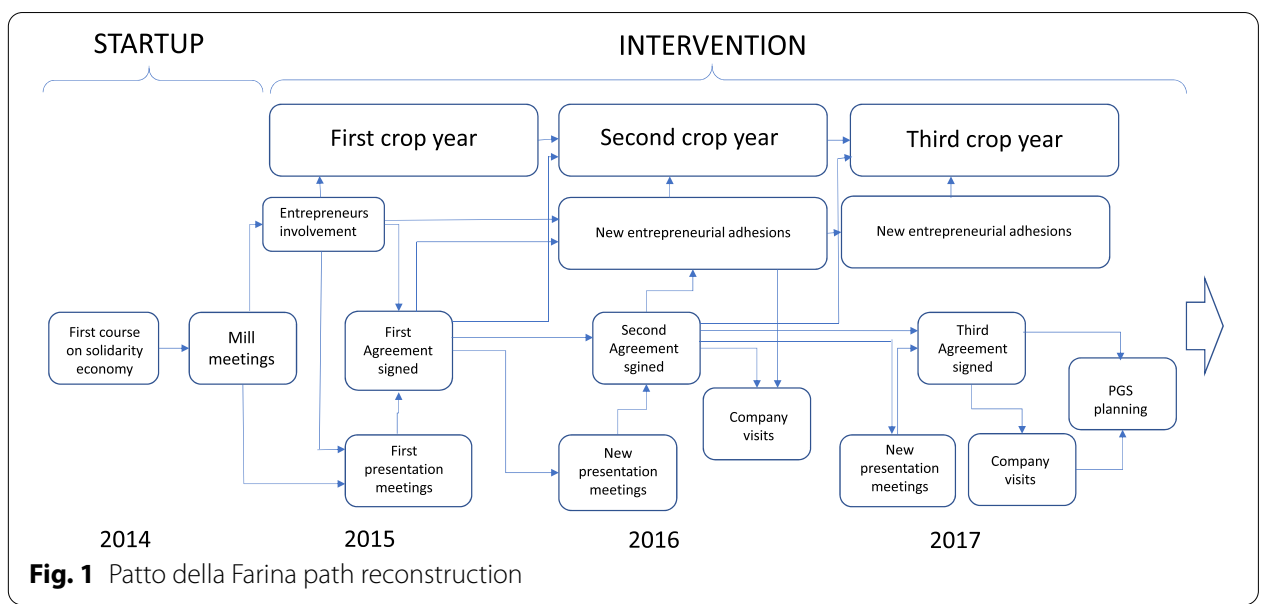

consequently, the added value of economic activities is kept and shared within the territory (Porter and Kramer 2011), and further contributes to local development.

Patto della Farina del Friuli Orientale-The Patto della Farina del Friuli Orientale is a short food supply chain agreement which aims at changing social and market relationships between consumers and producers. The spatial dimension of the project covers some $2500 \mathrm{~km}^{2}$ in the central and eastern areas of Friuli Venezia Giulia, namely, the provinces of Trieste and Gorizia, and part of the province of Udine. In 2014 the FBC supported the definition of an agreement between two local farmers, a miller, a baker, and a group of consumers concerned about the production and transformation of organic flour and bread from ancient wheat varieties. At the beginning of every crop year, producers and consumers negotiate fair prices for the products, with the former transparently presenting production costs, and the latter committing to buy at least $10 \mathrm{~kg}$ of flour per family during the year; in this phase, consumers pay in $10 \%$ of their expected total expense, as a liquidity base for producers. Throughout the year, consumers are periodically updated on the production process and get to visit the wheat fields and the participating businesses; they share the entrepreneurial risk and build relationships among them and with the producers. At present, 10 to 12 hectares of land are cultivated using conservation agriculture practices, including minimum tillage, soil mulching and genetic diversification through mixing ancient wheat varieties. On the point of view of the consumers, the personal and economic commitment is counterbalanced by the warranty of high-quality products sold at competitive prices; conversely, committed entrepreneurs have access to an alternative and more remunerative market. The ongoing attempt to organize and establish a participatory guarantee system (PGS) is likely to further enhance these aspects (Sacchi 2019). PGS is an institutional system based on mutual trust, through which consumers and producers negotiate and together define quality and ethical standards of production, and share responsibility on monitoring and compliance (Montefrio and Johnson 2019; Niederle et al. 2020). In general terms, PGS potentially generates positive externalities in terms of opportunities for local development, protection of rural communities, biodiversity and landscape preservation, and overall contribution to community resilience (Home et al. 2017). Figure 1 presents the path reconstruction of the initiative. 


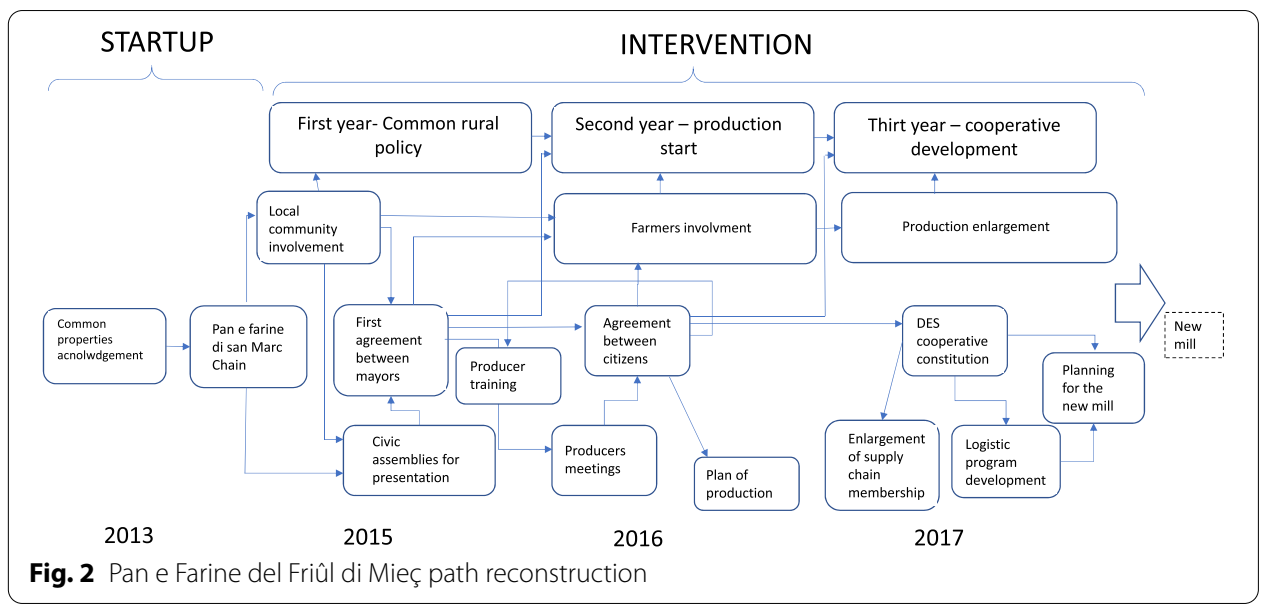

Pan e Farine del Friûl di Mieç-The Pan e Farine del Friûl di Mieç is a short food supply chain initiative for the production of flour and bread. The Municipality of Mereto di Tomba first launched the experiment in 2014, as an attempt to boost and enlarge a small local commons management project over 5 hectares of common arable land of the San Marco hamlet community. Three neighboring municipalities officially joined the project through a public agreement and, with the support of the FBC, started working together to establish a local solidarity economy district. The four predominantly rural townships extend over $138.11 \mathrm{~km}^{2}$, and count 12,943 inhabitants (Italian National Institute of Statistics, Istituto Nazionale di Statistica, ISTAT 2017). The process started with the constitution of a joint commission in charge of drawing up a shared agricultural policy. Subsequently, the city councils convened public meetings to involve local farmers and check their willingness to participate in the initiative. As of today, ten farms have joined the project, one of them being run by the organization in charge of the management of local commons, and produce organic wheat on about 25 hectares; moreover, they have organized themselves in an agricultural cooperative, established in December 2016. Bakeries from the project area and surrounding towns have also joined the supply chain project. At present, local administrators have stepped aside, and participate as guarantors of the process and to provide institutional support. A new mill was activated in 2018 by a private party involved in the project. The process transition path is summarized in Fig. 2.

Pan e Farine di Muçane-The Pan e Farine di Muçane is a short food supply chain initiative for the production of flour and bread. The territory of Muzzana, in Lower Friuli, counts 2660 inhabitants spread over $24.32 \mathrm{~km}^{2}$ (ISTAT 2017), with common lands covering a surface area of 352 ha, among which 162 ha of lowland forest and 181 hectares of arable land. In light of the positive experience of the Middle Friuli micro-supply chain, the Pan e Farine di Muçane initiative started out in 2014 as an attempt of the city council to innovate the management of local commons, in order to promote environmental protection and land development. The first, necessary step to launch the supply chain initiative was the conversion to organic farming of 90 ha of common arable land, completed and certified in 2016, and the subsequent decision to allocate 20 ha to wheat and spelt (Triticum spelta) production. At present, only 100 quintals of the total wheat and spelt production enter the supply chain through sale to a partner social cooperative, which 


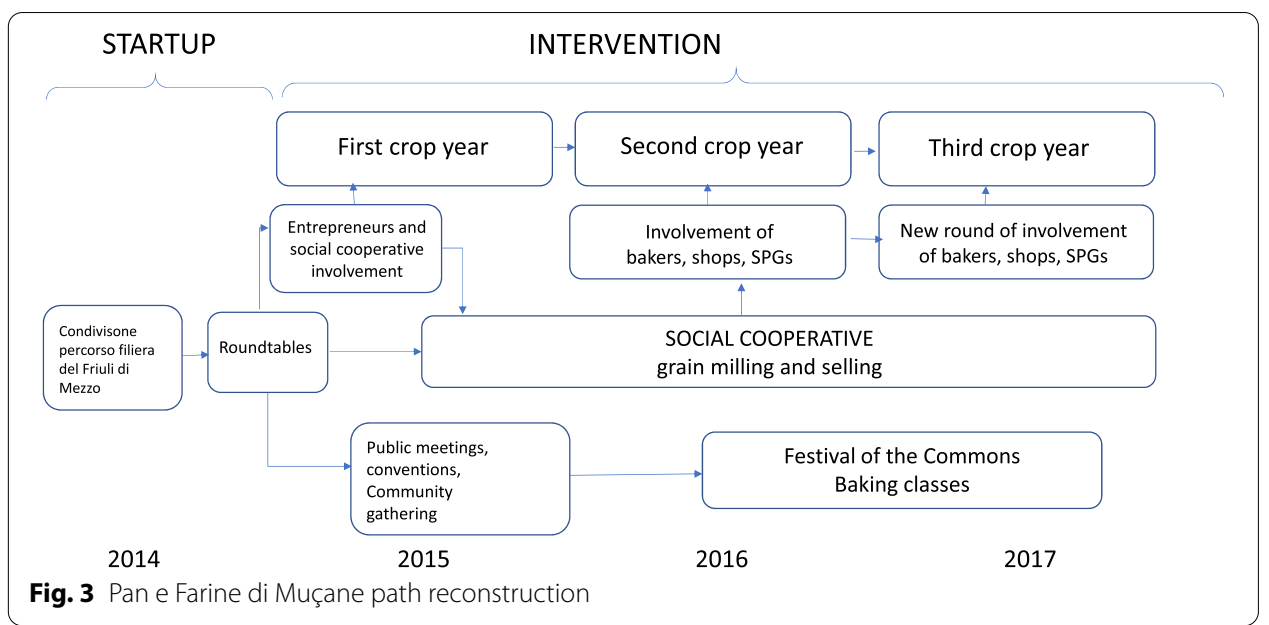

takes care of the milling and selling; the remaining share of production is sold through public tender. The cooperative is also in charge of managing relationships with bakers and resellers in the area. Since 2017, the local administration has organized the local Feast of the Commons (Festa dei Beni comuni), an annual celebration gathering to raise and increase awareness on commons, civic goods, and their management, and promote the local solidarity economy initiative. Conferences and seminars on organic farming and short supply chains, as well as free and open bread-making workshops liven up the event. The process transition path is summarized in Fig. 3.

\section{Results and discussion}

As already mentioned, the core of the three case studies here presented is the establishment of a local, short supply chain for the production and transformation of wheat and flour. Short supply chains characterize different production and consumption models, such as on-farm direct sales, farmers' markets, SPGs (Brunori and Bartolini 2013, p. 56). The common traits of these models are: the disintermediation of the supply chain; the emergence of direct relationships between producers and consumers; the local extent of the initiative, intended as the possibility for the actors within a specific territory to act and self-organize (Tecco et al. 2017, p. 36; Dematteis and Governa 2005).

In light of these considerations, a short supply chain is based on closeness between producers and consumers, in terms of geographical proximity, social interaction and communication, and circulation of the economic value within the territory (Galli and Brunori 2013).

The following tables summarize the main findings of our study and ease comparisons among the selected initiatives (Table 1).

The findings are presented here in line with the six research dimensions.

With respect to the initiators and key players, a bottom-up or top-down approach differentiates the examined experiences (Table 2). In one case, a young entrepreneur started to work closely and autonomously with a local NGO to promote a new solidarity economy initiative; the other two experiences, on the contrary, were originally fostered by local governments in conjunction with citizens. With respect to the Patto della Farina experience, the FBC acted as a container in which citizens and initiators 
Table 1 Main characteristics WHAT

\begin{tabular}{|c|c|c|c|}
\hline Evaluation criteria & $\begin{array}{l}\text { Patto della Farina del } \\
\text { Friuli Orientale }\end{array}$ & Pan e farine di Muçane & $\begin{array}{l}\text { Pan e farine dal Friûl di } \\
\text { Mieć }\end{array}$ \\
\hline \multicolumn{4}{|l|}{ Main characteristics } \\
\hline Intervention sector & $\begin{array}{l}\text { Wheat-to-bread supply } \\
\text { chain }\end{array}$ & $\begin{array}{l}\text { Wheat-to-bread supply } \\
\text { chain }\end{array}$ & $\begin{array}{l}\text { Wheat-to-bread supply } \\
\text { chain }\end{array}$ \\
\hline Objective definition & $\begin{array}{l}\text { Agronomic; environmen- } \\
\text { tal; organizational }\end{array}$ & $\begin{array}{l}\text { Agronomic; Environmen- } \\
\text { tal; Social }\end{array}$ & $\begin{array}{l}\text { Environmental; Economic; } \\
\text { Social }\end{array}$ \\
\hline Output & Flour, artisanal bread & $\begin{array}{l}\text { Flour, Artisanal bread, } \\
\text { pasta }\end{array}$ & $\begin{array}{l}\text { Flour, Artisanal/semi-indus- } \\
\text { trial?? bread }\end{array}$ \\
\hline Production & $\begin{array}{l}2015-80 q \\
2016-140 q \\
2017-200 q\end{array}$ & 100 q/year [stable] & 700 q/year [increasing] \\
\hline Product certification & $\begin{array}{l}\text { No formal certification; } \\
\text { ongoing PGS develop- } \\
\text { ment }\end{array}$ & $\begin{array}{l}\text { Organic certification } \\
\text { [total] }\end{array}$ & Organic certification [part] \\
\hline $\begin{array}{l}\text { Order production and } \\
\text { management }\end{array}$ & $\begin{array}{l}\text { Email; phone } \\
\text { Individual communica- } \\
\text { tion; group communica- } \\
\text { tion }\end{array}$ & Direct contact & Email; Direct contact \\
\hline $\begin{array}{l}\text { Sale and distribution } \\
\text { logistics }\end{array}$ & $\begin{array}{l}\text { Direct sale; home delivery; } \\
\text { direct and indirect dis- } \\
\text { tributors }\end{array}$ & Cooperative; local shops & $\begin{array}{l}\text { Direct sale; small producers; } \\
\text { carrier; local shops }\end{array}$ \\
\hline
\end{tabular}

Table 2 Startup HOW

\begin{tabular}{|c|c|c|c|}
\hline Evaluation criteria & $\begin{array}{l}\text { Patto della Farina del } \\
\text { Friuli Orientale }\end{array}$ & Pan e farine di Muçane & $\begin{array}{l}\text { Pan e farine dal Friûl di } \\
\text { Mieć }\end{array}$ \\
\hline \multicolumn{4}{|l|}{ Startup } \\
\hline $\begin{array}{l}\text { Startup process descrip- } \\
\text { tion }\end{array}$ & Path reconstruction (Fig. 1) & Path reconstruction (Fig. 2) & Path reconstruction (Fig. 3) \\
\hline Meeting summoner & $\begin{array}{l}\text { Entrepreneur (miller)—- } \\
\text { FBC }\end{array}$ & Municipal administration & Municipal administrations \\
\hline Involvement modes & $\begin{array}{l}\text { Participants' meetings; } \\
\text { public meetings and con- } \\
\text { ferences; company visits }\end{array}$ & $\begin{array}{l}\text { Training courses; working } \\
\text { table; public meetings }\end{array}$ & \\
\hline $\begin{array}{l}\text { Communication and sum- } \\
\text { mon channels }\end{array}$ & $\begin{array}{l}\text { Electronic mailing list; } \\
\text { Facebook; local press; } \\
\text { word-of-mouth }\end{array}$ & $\begin{array}{l}\text { Community gatherings } \\
\text { convened by mayor; local } \\
\text { press; Facebook }\end{array}$ & $\begin{array}{l}\text { Community gatherings } \\
\text { convened by mayor; local } \\
\text { press; Facebook }\end{array}$ \\
\hline $\begin{array}{l}\text { Merchandising, informa- } \\
\text { tion material }\end{array}$ & Flyers & Brochures & Brochures \\
\hline Brand/logo & No & Unregistered trade mark & Unregistered trade mark \\
\hline
\end{tabular}

could gather together, and sow the seeds of the initiative; thereafter, engaged entrepreneurs heavily contributed to the development of the experiment, by coordinating and managing production and logistics as well as the civic initiative. Conversely, local administrators designed and took the lead of the other two initiatives, which share the similar agronomic aim of crop reconversion; in addition, civil society's role is enhanced in the Friûl di Mieç case, with citizens and producers gradually replacing local administrators in managerial positions, and the promotion of local networks at the base of the solidarity economy district.

The three initiatives share the call for citizens' responsibility in supporting and sharing the experiments (Tables 3,4). Due to the focus on the realization of local, 
Table 3 Assessment - the role of the community

\begin{tabular}{|c|c|c|c|}
\hline Evaluation criteria & $\begin{array}{l}\text { Patto della Farina del } \\
\text { Friuli Orientale }\end{array}$ & Pan e farine di Muçane & $\begin{array}{l}\text { Pan e farine dal Friûl di } \\
\text { Mieć }\end{array}$ \\
\hline \multicolumn{4}{|c|}{ Impact evaluation - the community } \\
\hline $\begin{array}{l}\text { Community of reference } \\
\text { and its evolution }\end{array}$ & $\begin{array}{l}\text { Elective community } \\
\text { (ethical consumers from } \\
\text { all over the region)- } \\
\text { pre-existing subgroups } \\
\text { (neighborhood commit- } \\
\text { tee, GAS) }\end{array}$ & $\begin{array}{l}\text { Territorial/Elective com- } \\
\text { munity Municipality of } \\
\text { Muzzana residents; weak } \\
\text { ties with outsiders }\end{array}$ & $\begin{array}{l}\text { Territorial-Residents in the } \\
4 \text { municipalities of Medio } \\
\text { Friuli } \\
\text { Elective community-Other } \\
\text { industry actors from sur- } \\
\text { rounding area }\end{array}$ \\
\hline $\begin{array}{l}\text { Spatial extent of the } \\
\text { initiative }\end{array}$ & $\begin{array}{l}\text { Potentially, the whole } \\
\text { region }\end{array}$ & $\begin{array}{l}\text { Muzzana municipality and } \\
\text { Friuli lowland }\end{array}$ & $\begin{array}{l}\text { Recognizable—the } 4 \\
\text { municipalities of Medio } \\
\text { Friuli }\end{array}$ \\
\hline Local institutions' role & Absent & $\begin{array}{l}\text { Agricultural production } \\
\text { management; process } \\
\text { guarantee }\end{array}$ & $\begin{array}{l}\text { Guarantors of the interac- } \\
\text { tions among participants }\end{array}$ \\
\hline $\begin{array}{l}\text { Community } \\
\text { Self-awareness/identity }\end{array}$ & $\begin{array}{l}\text { Mixed-stronger } \\
\text { subgroup identity (GAS, } \\
\text { neighborhood); shared } \\
\text { values; lack of external } \\
\text { recognition }\end{array}$ & $\begin{array}{l}\text { Low among Muzzana } \\
\text { inhabitant-mixed level } \\
\text { of awareness among } \\
\text { generic consumers }\end{array}$ & $\begin{array}{l}\text { Strong identity of the origi- } \\
\text { nal group (Pan di San Marc); } \\
\text { mixed level of awareness of } \\
\text { generic consumers }\end{array}$ \\
\hline $\begin{array}{l}\text { Participants'sense of } \\
\text { responsibility }\end{array}$ & $\begin{array}{l}\text { High_entrepreneurs } \\
\text { Mixed_consumers }\end{array}$ & $\begin{array}{l}\text { High_Municipality } \\
\text { of Muzzana and social } \\
\text { cooperative }\end{array}$ & $\begin{array}{l}\text { High_producers bear } \\
\text { entrepreneurial risk }\end{array}$ \\
\hline Networks & Regional, diffused & Sub-regional, diffused & Local, UTI-based \\
\hline
\end{tabular}

Table 4 Assessment-sustainability

\begin{tabular}{|c|c|c|c|}
\hline Evaluation criteria & $\begin{array}{l}\text { Patto della Farina del } \\
\text { Friuli Orientale }\end{array}$ & Pan e farine di Muçane & $\begin{array}{l}\text { Pan e farine dal Friûl di } \\
\text { Mieć }\end{array}$ \\
\hline \multicolumn{4}{|l|}{ Assessment_-sustainability } \\
\hline $\begin{array}{l}\text { Volunteer participation and } \\
\text { duties }\end{array}$ & $\begin{array}{l}\text { Functional_distribution } \\
\text { organization and manage- } \\
\text { ment; meeting manage- } \\
\text { ment; communication } \\
\text { (conferences...) } \\
\text { Informal—word-of-mouth } \\
\text { communication }\end{array}$ & $\begin{array}{l}\text { Informal-word-of- } \\
\text { mouth communication }\end{array}$ & $\begin{array}{l}\text { Functional-distribution } \\
\text { organization and manage- } \\
\text { ment; communication; } \\
\text { events } \\
\text { Informal-word-of-mouth } \\
\text { communication }\end{array}$ \\
\hline Induced jobs & Indirect (seasonal) & 2 (social cooperative) & 2 (part-time) \\
\hline Community changes & $\begin{array}{l}\text { Leading group has not } \\
\text { changed; individual } \\
\text { participation has created a } \\
\text { melting pot rather than a } \\
\text { community }\end{array}$ & Not significant & $\begin{array}{l}\text { Increased sense of identity } \\
\text { and belonging }\end{array}$ \\
\hline $\begin{array}{l}\text { Changes in consumption } \\
\text { models }\end{array}$ & $\begin{array}{l}\text { Increased awareness on } \\
\text { sustainable consumption; } \\
\text { self-production }\end{array}$ & Low & $\begin{array}{l}\text { Increased awareness on } \\
\text { quality productions }\end{array}$ \\
\hline
\end{tabular}

sustainable, and ethical food systems, all these experiences fall under the Alternative Food Network (AFN) category (Whatmore et al. 2003). Moreover, the initiatives rely on the existence of an agreement as a constituent element, even though the degree of formalization may vary: producers and consumers participating in the Patto della Farina initiative publicly sign a written contract as a demonstration of the shared commitment; mayors from middle Friuli initially used contractualization to define shared agricultural policies, then opened up to farmers, with the long-term objective 
Table 5 Assessment-coherence with regional law (4/2017)

\begin{tabular}{|c|c|c|c|c|}
\hline Evaluation criteria & L.R art & $\begin{array}{l}\text { Patto della Farina del } \\
\text { Friuli Orientale }\end{array}$ & $\begin{array}{l}\text { Pan e farine di } \\
\text { Muçane }\end{array}$ & $\begin{array}{l}\text { Pan e farine dal Friûl } \\
\text { di Mieć }\end{array}$ \\
\hline \multicolumn{5}{|l|}{ Assessment_-sustainability } \\
\hline $\begin{array}{l}\text { Solidarity and reciproc- } \\
\text { ity }\end{array}$ & Art.1 & Trough agreement & Civic uses Regulation & $\begin{array}{l}\text { Constitutive act of the } \\
\text { cooperative }\end{array}$ \\
\hline $\begin{array}{l}\text { Environmental sustain- } \\
\text { ability }\end{array}$ & Art.1 & $\begin{array}{l}\text { Non-certified organic } \\
\text { production }\end{array}$ & $\begin{array}{l}\text { Certified organic pro- } \\
\text { duction }\end{array}$ & $\begin{array}{l}\text { Certified organic pro- } \\
\text { duction }\end{array}$ \\
\hline Social Cohesion & Art.1 & Not addressed & Not addressed & Not addressed \\
\hline Community & Art.3 & Elective & Institutional & Territorial \\
\hline Commons good & Art.3 & None & Common properties & Common properties \\
\hline $\begin{array}{l}\text { Solidarity economy } \\
\text { business/entrepreneur- } \\
\text { ship }\end{array}$ & Art.3 & None & Social cooperative & Community cooperative \\
\hline Local Chain & Art.3 & Food chain & Food chain & Food chain \\
\hline Agreement & Art.3 & Between citizens & None & Between municipalities \\
\hline
\end{tabular}

to get all the participants to sign an agreement; finally, the Muzzana experience makes use of a contract between the municipality and the social cooperative.

Each initiative is based on a local community that is a group of individuals who identify themselves with respect to territorial belonging, whose spatial extent may vary from village boundaries, as in the case of Muzzana, to broader though defined and recognizable territories. In addition to local identity, communities are based on and defined by the sharing of common values (Table 4), which reflects the concept of 'project identities' (Castells 1997). The sense of identity built upon a shared initiative is the core element of elective communities (Gangemi 2006). This process is clearly identifiable in the Patto della Farina initiative, whose community groups pre-existing communities characterized by close adherence to strong ethics and values. The Medio Friuli experience pairs the pre-existing local community with a broader community project which crosses the geographical borders of the municipality. In Muzzana, on the contrary, local administrators have been more effective in involving outsiders rather than their own fellow citizens, and the community composition reflects the cooperative's ability to engage different stakeholders from the lowlands of Friuli.

Regarding the spatial extent, the three supply chain initiatives vary in size, even though they are all based on proximity. The Patto della Farina is rooted in Eastern Friuli and the main eastern cities of the region; moreover, the PGS project is likely to attract producers from across the region. The Medio Friuli supply chain is expanding among producers, resellers and consumers, outside, and around the Medio Friuli district. The actors of the Muzzana initiative, bakers, resellers and producers, are distributed in a patchy way all over the region lowlands. While the spatial extent conventionally associated with farmto-fork models is usually bidimensional and centered on the actual geographical distance between producer and consumer, the three supply chains presented in this paper have created bioregions (Berg and Dassman 1977), which embed territorial, social, and cultural elements in relational spaces (Harvey 2006; Tecco et al. 2017).

If analyzed under the framework of regional law n. 4/2017, the three projects mostly comply with legal provision, even though, once again, following unique paths (Table 5). The principles of solidarity economy identified by the law are explicitly incorporated in 
Table 6 New/recent development

\begin{tabular}{|c|c|c|c|}
\hline Evaluation criteria & $\begin{array}{l}\text { Patto della Farina del } \\
\text { Friuli Orientale }\end{array}$ & Pan e farine di Muçane & $\begin{array}{l}\text { Pan e farine dal Friûl di } \\
\text { Mieć }\end{array}$ \\
\hline \multicolumn{4}{|l|}{ New/recent developments } \\
\hline New projects & $\begin{array}{l}\text { Product differentiation; } \\
\text { ancient mill renovation; } \\
\text { PGS }\end{array}$ & $\begin{array}{l}\text { FVG Rural Development } \\
\text { Programme (funding for } \\
\text { organic agriculture) }\end{array}$ & $\begin{array}{l}\text { FVG Rural Development } \\
\text { Programme (innovation } \\
\text { hub); New private mill }\end{array}$ \\
\hline Monitoring & PGS planning & No & Partial \\
\hline Organizational model & $\begin{array}{l}\text { No formalization is neces- } \\
\text { sary; perhaps, enterprise } \\
\text { network without rigid } \\
\text { structure }\end{array}$ & Formal (social cooperative) & $\begin{array}{l}\text { Formalization of a DES } \\
\text { cooperative; eventually, } \\
\text { citizens'association }\end{array}$ \\
\hline Future plans & $\begin{array}{l}\text { Either spatial enlargement } \\
\text { (economies of scale) or } \\
\text { local capillary presence }\end{array}$ & New mill & $\begin{array}{l}\text { Direct selling point; packing } \\
\text { plant }\end{array}$ \\
\hline Recognitions/awards & None & Rural excellence & $\begin{array}{l}\text { Coldiretti Oscar Green } \\
\text { First Slow Food community } \\
\text { in the FVG Region }\end{array}$ \\
\hline Main weaknesses & $\begin{array}{l}\text { Widespread community } \\
\text { with weak ties [self-refer- } \\
\text { entiality] }\end{array}$ & Small mill & Logistics \\
\hline Main point of strength & Flexibility & $\begin{array}{l}\text { Armony between agricul- } \\
\text { ture and nature }\end{array}$ & $\begin{array}{l}\text { Farmers and volunteers' } \\
\text { involvement }\end{array}$ \\
\hline
\end{tabular}

the initiatives. Solidarity and reciprocity are embedded in the initiatives, either through formal regulations (the Regulation on Civic uses in Muzzana), legal acts (the Constitutive Act of the Community Cooperative in Medio Friuli), or informal agreements (as in the Patto della Farina case). The main focus on environment and landscape protection is expressed through the adoption of conservation and organic agriculture, even though the Patto della Farina community rejected the certification proposal. The communities gravitating around the three projects are defined and identified according to different criteria, either territorial (Pan e farine dal Friûl di Mieć), institutional (Pan e farine di Muçane) or based on the commonality of interests and values (Patto della Farina): this heterogeneity is partly in contrast with the law, whose definition of solidarity economy community includes specific spatial and administrative boundaries. The principle of social cohesion, described in Article 1 of the regional law, is not formally addressed in any project. One of the key elements of the two institutionalized projects is the management of common goods (common properties and civic uses in both cases), while this aspect is lacking in the Patto della Farina case. This also impacts the capacity of the initiatives to create actual solidarity economy business and promote social entrepreneurship: while the experiences of Pan e farine di Muçane and Pan e farine dal Friûl di Mieć fostered the constitution of social and community cooperatives, the businesses involved in the Patto della Farina were already existing, and they have decided to integrate solidarity economy principles in their conventional entrepreneurial and market activities.

The different approaches and principles followed by each initiative and its community also determine the evolution and future perspectives (Table 6). The Pan e farine di Muçane and Pan e farine dal Friûl di Mieć, in which institutional participation has played a major role since the beginning, foresee further structurization and physical expansion through the establishment of new facilities (mill, packing plant, direct selling points) and formalization of the activities (i.e., foundation of project cooperatives 
and citizen associations). Conversely, the actors involved in the Patto della Farina aim at enhancing trust in their relationships (PGS initiative) and expanding a community based on shared values, rather than specific territorial borders.

\section{Conclusion}

This research presents a qualitative evaluation of, and comparison among three local initiatives from Friuli Venezia Giulia, focusing on the processes which created their respective communities as well as their ongoing evolution and perspectives. Multiple authors state that the description of solidarity economy relies on the analysis of good practices and experiences aimed at pursuing well living by meeting community and individuals' needs, and nutrition above all.

The preliminary analysis of the information gathered highlights the role of the L. R. 4/2017 as the shared background of the three case studies. In fact, albeit differences in their origin and development, the key elements envisioned in the L.R. 4/2017-short supply chain organization and community development-constitute the main pillars of the three experiences; nevertheless, each community is unique in its territorial structure. In fact, while the L.R. 4/2017 defines the spatial extent of solidarity economy communities as limited to the UTIs, the Pan e Farine del Friûl di Mieç and Pan e Farine di Muçane communities are embedded in specific territorial dimensions, and the community revolving around the Patto della Farina is built on a commonality of intent and interests.

The reconstruction of the transition paths, together with documental analysis and interviews, allowed us to deduce the influence of alternative approaches, and subsequent degree of effectiveness in building a community and driving it toward sustainability. In this context, the qualitative approach proves useful to understand the social reality and evolutionary trends which characterize the paths of the three communities toward sustainable development. Further work needs to be done to estimate the actual impact of these transition paths and their overall effects on community sustainability. We therefore propose that future research should also consider quantitative analysis of indicators of economic, social, and environmental performance, to be used as evaluation and management tools (Moroke et al. 2019; Scipioni et al. 2009; Valentin and Spangenberg 2000).

Besides the evaluation of the specific cases, the analysis provides useful insights to better understand general dynamics and foresee the evolution of transition initiatives: how are communities organizing themselves to tackle the systemic crisis of Western societies? Which strategies and processes are they adopting to cope with environmental issues? What is the size of these communities? Which legal frameworks are they adopting?

Acknowledgements

Not applicable.

Authors' contributions

LP conceived the original research idea. LP, NC, MC designed the research methods. LP focused on the "Pan e Farine del Friûl di Mieç" case study; NC focused on "Pan e Farine di Muçane" case study; MC focused on the "Patto della Farina" case study. All authors have contributed equally to writing and revising the manuscript. All authors read and approved the final manuscript.

Funding

This research received no specific grant from any funding agency in the public, commercial, or not-for-profit sectors. 
Availability of data and materials

The data that support the findings of this study are available from the corresponding author upon reasonable request.

\section{Declarations}

\section{Competing interests}

The authors declare that they have no competing interests.

\section{Author details}

'Department of Agricultural, Food, Environmental and Animal Sciences, University of Udine, Via delle Scienze 206, Udine, Italy. ${ }^{2}$ Department of Economics, Business, Mathematics and Statistics, University of Trieste, Via dell'Università 1, Trieste, Italy. ${ }^{3}$ Department of Humanities and Cultural Heritage, University of Udine, Vicolo Florio 2/B, Udine, Italy.

Received: 23 March 2021 Revised: 31 August 2021 Accepted: 3 September 2021

Published online: 02 December 2021

\section{References}

Bauhardt C (2014) Solutions to the crisis? The green new deal, degrowth, and the solidarity economy: alternatives to the capitalist growth economy from an ecofeminist economics perspective. J Ecol Econ 102(61):60-68

Berg P, Dassman R (1977) Reinhabiting California. Ecologist 7(10):399-401

Brangwyn B, Hopkins R (2008) Transition initiatives primer. TransitionNetwork.org

Brunori G, Bartolini F (2013) La filiera corta: le opportunità offerte dalla nuova Pac. Agriregioneuropa 9(35):55-60

Brunori G, Rossi A, Guidi F (2012) On the new Social Relations around and beyond food. Analysing consumers' role and action in Gruppi di Acquisto Solidale (Solidarity Purchasing Groups). Sociol Rural 52(1):1-30

Castells M (1997) The Power of Identity (The Information Age: Economy, Society and Culture), vol 2. Blackwell

Chaves Avila R, Gallego Bono JR (2020) Transformative policies for the social and solidarity economy: the new generation of public policies fostering the social economy in order to achieve sustainable development goals. The European and Spanish cases. Sustainability 12:4059. https://doi.org/10.3390/su12104059

Connors P, McDonald P (2011) Transitioning communities: community, participation and the Transition Town movement. Community Dev J 46(4):558-572

Dematteis G, Governa F (eds) (2005) Territorialità, sviluppo locale, sostenibilità: il modello Slot. FrancoAngeli

Dunn J, Bradford N, Evans J (2010) Place-based policy approaches: practical lessons and applications. Report prepared for Community Development and Partnership, Human Resources and Skill Development Canada

Felicetti A (2013) Localism and the transition movement. Policy Stud 34(5-6):559-574

Feola G, Nunes R (2014) Success and failure of grassroots innovations for addressing climate change: the case of the transition movement. Glob Environ Change 24:232-250

Fonte M, Cucco I (2017) Cooperatives and alternative food networks in Italy. The long road towards a social economy in agriculture. J Rural Stud 53:291-302

Forrest N, Wiek A (2014) Learning from success-toward evidence-informed sustainability transitions in communities. Environ Innov Soc Trans 12:66-88

Galli F, Brunori G (eds) (2013) Short food supply chains as drivers of sustainable development. Evidence document. Laboratorio di studi rurali Sismondi

Galli F, Bartolini F, Brunori G, Colombo L, Gava O, Grando S, Marescotti A (2015) Sustainability assessment of food supply chains: an application to local and global bread in Italy. Agric Food Econ 3:21

Gangemi G (2006) Democrazia, sussidiarietà e reti sul territorio. In: Donolo C (a cura di) II futuro delle politiche. Mondadori, pp 189-204

Gomez-Alvarez R (2016) The economy for the common good and the social and solidarity economies, are they complementary? CIRIEC-España, Revista De Economía Pública, Social y Cooperativa 87:257-294

Guerra P (2009) La economía de la solidaridad. O la vuelta de los valores sociales a la economía. http://base.socioeco.org/ docs/la-economia-de-la-solidaridad-pablo-guerra-uruguay.pdf

Guerra P (2014) Socioeconomía de la solidaridad. Una teoría para dar cuenta de las experiencias sociales y económicas alternativas. Ediciones Universidad Cooperativa de Colombia

Harvey D (2006) Space as a keyword. In: Harvey D (ed) A Critical Reader. Blackwell, pp 70-93. https://doi.org/10.1002/ 9780470773581.ch14

Haxeltine A, Seyfang G (2009) Transitions for the people: theory and practice of "transition" and "resilience" in the UK's transition movement. Tyndall Centre, pp 1-24

Hinrichs CC (2000) Embeddedness and local food systems: notes on two types of direct agricultural market. J Rural Stud 16(3):295-303

Home R, Bouagnimbeck H, Ugas R, Arbenz M, Stolze M (2017) Participatory guarantee systems: organic certification to empower farmers and strengthen communities. Agroecol Sustain Food Syst 41(5):526-545

Hudson L (2018) New York City: struggles over the narrative of the Solidarity Economy. Geoforum. https://doi.org/10. 1016/j.geoforum.2018.04.003

ISTAT (2017) Demografia in cifre. http://demo.istat.it/index.html

Kelly U, Kelly R (2017) Resilience, solidarity, agency-grounded reflections on challenges and synergies. Resilience $5(1): 10-28$

Laville JL (1998) L'Economia solidale. Bollati Boringhieri

Laville JL (2010) The solidarity economy: an international movement. RCCS annual review, 2. http://journals.openedition. org/rccsar/202 
Laville JL (2014) The social and solidarity economy: a theoretical and plural frame-work. In: Defourny J, Hulgård L, Pestoff $\checkmark$ (eds) Social enterprise and the third sector. Changing European landscapes in a comparative perspective. Routledge, pp 102-113

Luederitz C, Schäpke N, Wiek A, Lang DJ, Bergmann M, Bos JJ et al (2017) Learning through evaluation —a tentative evaluative scheme for sustainability transition experiments. J Clean Prod 169:61-76

Mälgand M, Bay-Mortensen N, Bedkowska B, Hansen FN, Schow M, Thomsen AA, Hunka AD (2014) Environmental awareness, the Transition Movement, and place: Den Selvforsynende Landsby, a Danish Transition initiative. Geoforum 57:40-47

Mance EA (2003) La rivoluzione delle reti: l'economia solidale per un'altra globalizzazione. EMl

Marsden T, Banks J, Bristow G (2000) Food supply chain approaches: exploring their role in rural development. Sociol Rural 40(4):424-438

Montefrio MJF, Johnson AT (2019) Politics in participatory guarantee systems for organic food production. J Rural Stud 65:1-11

Moraes Soares MN, Souza Lessa B, Cavalcante Aguiar IC, Leocadi AL, Dias Pedro Rebouça SM (2016) Clusters in the solidarity economy: the strategy of participating in networks of enterprises in Brazil. CIRIEC-España, Revista De Economía Pública, Socialy Cooperativa 86:35-59

Moroke T, Schoeman C, Schoeman I (2019) Developing a neighbourhood sustainability assessment model: an approach to sustainable urban development. Sustain Cities Soc 48:101433

Niederle P, Loconto A, Lemeilleur S, Dorville C (2020) Social movements and institutional change in organic food markets: evidence from participatory guarantee systems in Brazil and France. J Rural Stud 78:282-291

Petropoulou EA (2018) Social and solidarity economy. The case of an urban consumption co-operative in Greece. Open J Sociopolit Stud 11:70-94

Piani, L., and Minatelli, F. (2016). Distretti Filiere e patti nell'economia solidale italiana. In: I dialoghi dell'economia solidale, Trieste: Asterios, 122-138.

Polanyi K (1944) The great transformation. Beacon Press

Porter M, Kramer M (2011) Creating shared value. Harv Bus Rev 89(1-2):62-77

Razeto L (1993) Los caminos de la economía de solidaridad. Vivarium Ediciones

Renting H, Marsden TK, Banks J (2003) Understanding alternative food networks: exploring the role of short food supply chains in rural development. Environ Plan A 35(3):393-411

Renting H, Schermer M, Rossi A (2012) Building food democracy: exploring civic food networks and newly emerging forms of food citizenship. Int J Sociol Agric Food 19(3):289-307

Sacchi G (2019) Social innovation matters: the adoption of participatory guarantee systems within Italian alternative agrifood networks. Strateg Change 28(4):241-248

Sage C (2014) The transition movement and food sovereignty: from local resilience to global engagement in food system transformation. J Consum Cult 14(2):254-275

Scipioni A, Mazzi A, Mason M, Manzardo A (2009) The Dashboard of sustainability to measure the local urban sustainable development: the case study of Padua Municipality. Ecol Ind 9(2):364-380

Shawki N (2013) Understanding the transnational diffusion of social movements: an analysis of the US solidarity economy network and transition US. Humanit Soc 37(2):131-158

Silajdžić I, Kurtagić SM, Vučijak B (2015) Green entrepreneurship in transition economies: a case study of Bosnia and Herzegovina. J Clean Prod 88:376-384

Tecco N, Bagliani M, Dansero D, Peano C (2017) Verso il sistema locale territoriale del cibo: spazi di analisi e di azione. Bollettino Della Società Geografica Italiana, XIII 10:23-42

Valentin A, Spangenberg JH (2000) A guide to community sustainability indicators. Environ Impact Assess Rev 20(3):381-392

Van Der Schoor T, Scholtens B (2015) Power to the people: local community initiatives and the transition to sustainable energy. Renew Sustain Energy Rev 43:666-675

Whatmore S, Stassart P, Renting H (2003) What's alternative about alternative food networks? Environ Plan A 35:389-391

Williams M (2014) The solidarity economy and social transformation. In: Satgar V (ed) The solidarity economy alternative: emerging theory and practice. University of KwaZulu-Natal Press, pp 37-63

Wilson AD (2013) Beyond alternative: exploring the potential for autonomous food spaces. Antipode 45(3):719-737

Yin RK (2003) Case study research: design and methods, 3rd edn. Sage

\section{Publisher's Note}

Springer Nature remains neutral with regard to jurisdictional claims in published maps and institutional affiliations. 